Tsaqofiya : Jurnal Pendidikan Bahasa dan Sastra Arab

Vol. 3 No. 2 Juli 2021, 176-188

P-ISSN : 2685-7022, E-ISSN : 2685-7103

DOI : https://doi.org/10.21154/tsaqofiya.v3i2.75

\title{
PEMBELAJARAN IMLA' MELALUI MEDIA WHATSAPP DI KELAS III MI CEMOROKANDANG
}

\author{
M. Afief Akbari1, Muassomah² \\ Universitas Islam Negeri Maulana Malik Ibrahim Malang \\ 1akbariafief@gmail.com, ${ }^{2}$ muassomah@bsa.uin-malang.ac.id
}

\section{Abstract}

This study discusses: Imla' Learning \& the material exercises are carried out through Whatsapp media in class III MI Cemorokandang, and the impact of Imla' learning carried out. While the research method that researchers use in this study is a descriptive qualitative research method. Then after the data is collected, data analysis is carried out by: data reduction, data presentation and drawing conclusions. In this study, it can be seen that the stages of implementing Imla' learning in third grade students begin with greetings, prayers, then the teacher sends the material to be discussed to the group, 10 to 15 minutes after the material is distributed, the teacher and students can discuss or ask questions about the material that has been discussed. As explained earlier, the teacher then sends a text message or voice note to the group asking the students to do the exercises given, and in closing, they can re-deliver the material that has been discussed at a glance. The answer from the students or teachers of the Arabic language subject related to the Imla 'learning that has been carried out is that related to the practice of pronunciation \& writing, giving examples and others is considered satisfactory, it's just that when giving assignments it needs to be explained as clearly as possible.

Keywords: Imla' Learning, Learning Media, Whatsapp

\section{Asbtrak}

Penelitian ini membahas tentang: Pembelajaran Imla' \& latihan materinya dilaksanakan melalui media Whatsapp di kelas III MI Cemorokandang, dan dampak dari pembelajaran Imla' yang dilaksanakan. Sedangkan metode penelitian yang peneliti gunakan pada penelitian kali ini ialah metode penelitian kualitatif bersifat deskriptif. Kemudian setelah data terkumpul dilakukan analisis data dengan: reduksi data, penyajian data, dan penarikan kesimpulan. Pada penelitian ini dapat diketahui bahwa tahapan pelaksanaan pembelajaran Imla' pada murid kelas III diawali dengan salam, doa, kemudian guru mengirimkan materi yang akan dibahas ke grup, 10 hingga 15 menit setelah materi dibagikan, guru dan siswa bisa berdiskusi atau bertanya tentang materi yang sudah dijelaskan sebelumnya, selanjutnya guru mengirimkan pesan teks ataupun voice note ke grup yang berisi meminta para murid untuk mengerjakan latihan yang diberikan, dan dalam penutupan bisa menyampaikan ulang materi yang sudah dibahas secara sekilas. Jawaban dari murid ataupun guru mapel bahasa Arab terkait pembelajaran Imla' yang telah dilaksanakan ialah bahwa terkait pemraktikkan cara pengucapan \& cara penulisan, pemberian contoh dan lainnya dirasa sudah cukup memuaskan, 
hanya saja masukkannya yakni ketika memberi tugas agar perlu dijelaskan sejelas mungkin.

Kata kunci: Pembelajaran Imla', Media Pembelajaran, Whatsapp

\section{PENDAHULUAN}

Menulis huruf maupun kata secara benar merupakan salah satu hal ataupun sisi yang difokuskan bagi anak tingkat dasar/ibtidaiyah dalam pembelajaran bahasa Arab khususnya. Anggapan ataupun pernyataan ini tidak semata-mata muncul begitu saja, di beberapa kesempatan ketika peneliti berdiskusi ataupun bincang santai dengan teman-teman yang merupakan pengajar bahasa Arab di berbagai macam sekolah, mereka pun mengatakan hal yang demikian, bahwa para murid di sekolah dasar/madrasah Ibtidaiyah berupaya untuk selalu digenjot agar bisa menulis huruf maupun kata dalam bahasa Arab secara benar.

Sejauh ini, pembelajaran bahasa Arab terkhusus dalam materi Qowaidul Imla' bisa terlaksana sebagaimana normalnya, akan tetapi pada tahun 2020 ini, terhitung dari akhir Maret hingga sekarang ini (pertengahan Desember) kita dihadapkan dengan pandemi Covid-19 yang itu memberikan dampak kepada sisi apapun dan kepada siapapun, tanpa terkecuali dalam hal pendidikan ( kegiatan belajar mengajar). Mekanisme pembelajaran yang tadinya normal-normal saja, tiba-tiba mengharuskan kita untuk melakukan PJJ (Pembelajaran Jarak Jauh) atau pembelajaran dilaksanakan dalam jaringan. Hal ini tentunya membuat seluruh para pengajar (terkhusus pengajar bahasa Arab) untuk berupaya melaksanakan pembelajaran sebaik dan seefektif mungkin, yang itu diharapkan bisa tersampaikannya materi pokok yang sudah dirumuskan dalam rancangan pembelajaran. ${ }^{1}$

Sebagaimana yang dinyatakan Abdul Aziz dkk bahwa pembelajaran al-Imla' dapat meningkatkan kemampuan menulis tulisan Arab bagi santri di Pondok Pesantren Ar-Raudlatul Hasanah Medan dengan mengimplementasikan model desain pembelajaran Dick, Carey and Carey dengan langkahnya: identifikasi tujuan umum pembelajaran, melaksanakan analisis pembelajaran, identifikasi tingkah laku dan karakteristik awal siswa, merumuskan tujuan khusus pembelajaran, menyusun tes acuan patokan, mengembangkan strategi pembelajaran, mengembangkan dan

1 "Marshel Panik Harus CLBK Depan Mas menteri," Video YouTube, 16:25, dikirim oleh "TonightShowNet," 06 Oktober 2020, https://youtu.be/h TKGfHmL2w . 
memilih bahan pembelajaran, lalu mendesain dan melaksanakan evaluasi formatif. ${ }^{2}$ Sejalan dengan itu, Lalu Akmal Hijrat menunjukkan pembelajaran Khat Wa Qowa'idul Imla' bagi mahasiswa UIN Mataram diperlukan metode yang dapat mengantar dan membimbing mahasiswa kepada pengetahuan menulis yang baik dan benar. Selain itu penting juga memilih materi teks yang tidak terlalu sulit, sehingga tidak terlalu membebani para mahasiswa yang memiliki latar belakang pendidikan umum. ${ }^{3}$ Penelitian yang ada lebih menitikberatkan pada pembelajaran berbasis offline, sedangkan tulisan ini menitikberatkan pada pembelajaran berbasis online dengan menggunakan plaform WA.

Pembelajaran Imla' merupakan pembelajaran yang diberikan dalam rangka mengajari para murid agar bisa membentuk kata maupun huruf dengan bentuk yang benar berdasarkan kaidah Imla'4, dan latihan materinya terlaksana dengan cara guru membacakan beberapa kalimat, para siswa memahaminya dan kemudian menuliskannya, sedangkan dengan fenomena yang terjadi pada tahun 2020 ini, bisakah pelaksanaan pembelajaran Imla' yang seperti itu bisa dilaksanakan?

Oleh karena itu, tujuan dari penelitian ini adalah untuk mengetahui bagaimana pembelajaran Imla' \& latihan materinya itu dilaksanakan melalui media Whatsapp di kelas III MI Cemorokandang, dan untuk mengetahui bagaimana dampak dari pembelajaran Imla' yang dilaksanakan.

\section{METODE}

Penelitian kali ini menggunakan pendekatan kualitatif bersifat deskriptif. Mantra berpendapat di bukunya Moleong 5 menyampaikan metode kualitatif sebagai tahap ataupun prosedur penelitian yang memberikan hasil berbentuk data deskriptif berupa kata-kata atau lisan dari orang-orang dan perilaku yang bisa diperhatikan. Metode kualitatif berupaya memaparkan berbagai macam hal unik yang ada pada individu, kelompok, masyarakat, dan organisasi dalam kehidupan sehari-hari dengan

2 Mardianto Abdul Aziz S Syamsu Nahar, "Desain Pembelajaran Imla'dalam Meningkatkan Kemampuan Menulis Tulisan Arab Bagi Santri Di Pondok Pesantren Ar-Raudlatul Hasanah Medan," Edu-Riligia: Jurnal Ilmu Pendidikan Islam Dan Keagamaan 1, no. 4 (2017).

3 Lalu Akmal Hijrat, "Pembelajaran Khat Wa Qowa'idul Imla' Mahasiswa UIN Mataram Dan Problematikanya," Al-Islamiyah, Jurnal Pendidikan Dan Wawasan Studi Islam 2, no. 1 (2020): 1-8.

${ }^{4}$ Rini Rini, "Pembelajaran Kemahiran Menulis Bahasa Arab Aplikatif," Al-Muktamar As-Sanawi Li Al-Lughah Al-'Arabiyyah (MUSLA) 1, no. 1 (2020): 18-42.

5 Lexy J Moleong, Metodologi Penelitian Kualitatif, PT Remaja Rosdakarya (Bandung: PT Remaja Rosdakarya, 2009). 
cara menyeluruh, rinci, dalam, dan bisa dipertanggungjawabkan secara ilmiah 6 . Penelitian ini menyampaikan, mendeskripsikan ataupun menjelaskan tentang bagaimana pembelajaran Imla' \& latihan materinya dilaksanakan melalui media Whatsapp di kelas III MI Cemorokandang, dan juga bagaimana dampak dari pembelajaran Imla' yang dilaksanakan.

Selanjutnya terkait teknik pengumpulan data menggunakan teknik observasi, dokumentasi dan wawancara, yang itu kepada guru bahasa Arab dan beberapa murid kelas III MI Cemorokandang. Observasi dilakukan dengan melakukan pengamatan, yakni untuk mengamati bagaimana kegiatan belajar mengajar (dari pembukaan salam hingga penutup) yang terlaksana di kelas III MI Cemorokandang, yang itu bertujuan untuk penyesuaian ketika ingin melakukan praktik pengajaran. Wawancara dilaksanakan dengan 8 murid dilakukan secara online karena tidak memungkinkan bertatap muka secara langsung disebabkan pandemi yang masih mewabah. Wawancara ini bertujuan untuk mengetahui bagaimana dampak dari pembelajaran Imla' yang dilaksanakan menurut mereka. Sedangkan wawancara dengan satu guru, yaitu pak Aslam selaku guru mata pelajaran bahasa Arab di madrasah ini yang mana wawancara dengan beliau sendiri bertujuan untuk menggali informasi yang berkaitan dengan konsultasi terkait apa saja yang perlu diperhatikan dan dipersiapkan sebelum melakukan praktik mengajar dan juga menurut beliau setelah praktik mengajar itu dilaksanakan. Adapun dokumentasinya berupa foto, tangkapan layar (Whatsapp ataupun Zoom), yang dimaksudkan dalam menjelaskan data tentang kegiatan belajar mengajar yang terlaksana di kelas III MI Cemorokandang.

Setelah semua data yang ingin diambil telah didapatkan, selanjutnya dilakukan analisis data deskriptif. Proses analisis data dilakukan melalui tahapan; reduksi data: merangkum, memilih hal-hal yang pokok, memfokuskan pada hal-hal yang penting, dicari tema dan polanya dan membuang yang tidak perlu, penyajian atau display data: sekumpulan informasi tersusun yang memberi kemungkinan adanya penarikan kesimpulan, dan kesimpulan atau verifikasi: kegiatan ini dimaksudkan untuk mencari makna data yang dikumpulkan dengan mencari hubungan, persamaan, atau perbedaan. ${ }^{7}$

6 Sandu Siyoto and Muhammad Ali Sodik, Dasar Metodologi Penelitian (Literasi Media Publishing, 2015).

7 Siyoto and Sodik. 


\section{PEMBAHASAN}

\section{Pembelajaran Imla}

Tahapan dalam latihan menulis bahasa Arab yang pertama adalah Imla'. Imla' yang coba diungkapkan oleh Acef Hermawan ialah kategori menulis yang menekankan rupa atau postur huruf dalam menjadikan atau membuat kata-kata dan kalimat. Imla' yang coba didefinisikan oleh Mahmud Ma'ruf (1985: 157) adalah menulis huruf-huruf sesuai letak atau posisinya dengan benar dalam sebuah kata yang itu bertujuan untuk menjaga agar tidak terjadi kesalahan makna. ${ }^{8}$ Maka demikian Qowa'idul Imla' merupakan materi yang diberikan agar para mahasiswa atau peserta didik terbekali untuk mampu menulis Arab dengan baik dan benar. ${ }^{9}$

Di lain sumber Abdul Aziz dkk menyampaikan pengertian dari Imla (berbahasa Arab) di dalam artikelnya bahwa:

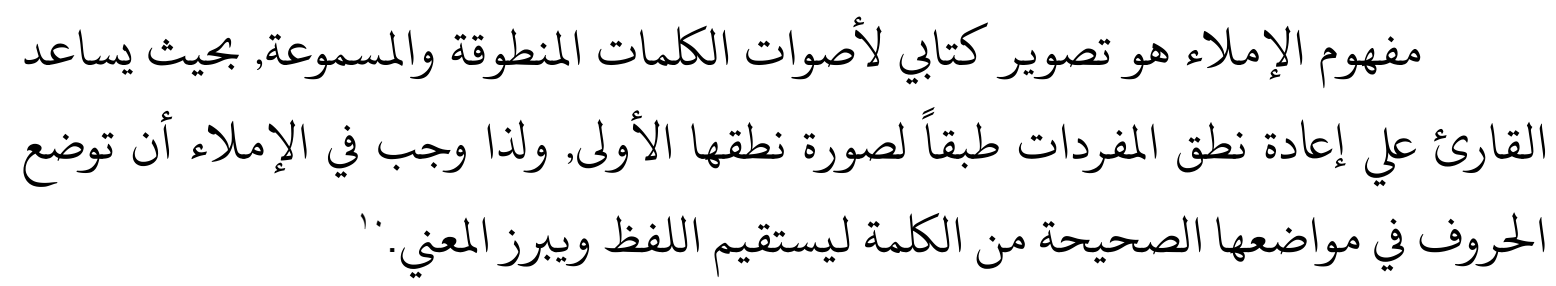

Maksudnya ialah Imla merupakan kegiatan menulis kata-kata yang diucapkan yang kemudian didengar, dimana pembaca memberi bantuan berupa pengulangan lafaz kata sesuai dengan lafaz yang dibaca di awal, maka dari itu di dalam Imla'peletakan hurufnya harus benar agar maknanya tepat.

\section{Tujuan Imla'}

Tujuan pembelajaran Imla' ialah sebagai berikut:

1) Memberikan praktek tanda baca

2) Menulis kata dan kalimat sehingga terbentuk dengan benar tanpa ada penambahan ataupun pengurangan, yang kemudian bisa membedakan terkait tulisan yang benar maupun yang salah

3) Melatih kebiasaan bagi para siswa dalam hal menjaga kebersihan tulisan, teliti, hati-hati, bisa mendengar dengan baik, cepat dan dapat menghubungkan antara teori dan praktek

${ }^{8}$ Ahmad Rathomi, "Maharah Kitabah Dalam Pembelajaran Bahasa Arab," Tarbiya Islamica 1, no. 1 (2020): 1-8.

9 Hijrat, "Pembelajaran Khat Wa Qowa'idul Imla' Mahasiswa UIN Mataram Dan Problematikanya."

10 Abdul Aziz S Syamsu Nahar, "Desain Pembelajaran Imla'dalam Meningkatkan Kemampuan Menulis Tulisan Arab Bagi Santri Di Pondok Pesantren Ar-Raudlatul Hasanah Medan.” 
4) Mengasah kemahiran menggerakkan tangan dan mata11

5) Melatih kecepatan berfikir, memahami makna dan karakter huruf

6) Mengasah indra pendengaran dan penglihatan agar tajam. ${ }^{12}$

\section{Macam-macam Imla'}

1. Imla' Manqul (الإملاء المنقول)

Di sini mahasiswa diharapkan bisa menulis huruf dan kata bahasa arab. Langkah yang dapat dilakukan ialah mahasiswa atau peserta didik diperintahkan atau ditugaskan untuk membaca teks berbahasa arab lalu menulisnya, yang mana ketika menulis boleh melihat tulisan yang sedang dipindahkan itu ke buku tulis. ${ }^{13}$

2. Imla' Mandhur (الإملاء المنظور)

Rathomi Ahmad menyampaikan dalam tulisanya bahwa Imla' Mandhur adalah peserta didik melihat teks berbahasa Arab yang ada di media tertentu dengan teliti, kemudian menuliskannya ke buku mereka dengan tidak melihat lagi tulisan tersebut. Imla' Mandhur bisa dilaksanakan dengan cara melatih siswa untuk mendengarkan potongan kalimat dengan tidak melihat tulisan kalimat tersebut, lalu mereka berdiskusi terkait arti kata atau kalimat dan membahas kata-kata yang dirasa susah. ${ }^{14}$

\section{Imla' Ikhtibariy (الإملاء الإختبار)}

Sedangkan tujuan dari Imla' Ikhtibary yakni untuk men-tashih terkait kemampuan yang dimiliki oleh peserta didik dari tiga sisi, yaitu kemampuan mendengar, menghafal dan menulis. Adapun praktiknya, peserta didik diharap agar benar-benar ketika mendengarkan kata atau kalimat yang diucapkan penguji, kemudian menghafalnya lalu ditulis. ${ }^{15}$

\section{Pelaksanaan pembelajaran Imla' melalui media Whatsapp}

Pada praktik pengajarannya, kegiatan belajar mengajar dengan anak-anak kelas III khususnya ataupun secara umum seluruh murid di MI Cemorokandang pada masa pandemi Covid-19 ini dilaksanakan melalui daring (Whatsapp, Zoom Meeting,

\footnotetext{
11 Rini, "Pembelajaran Kemahiran Menulis Bahasa Arab Aplikatif."

12 Riyadi Muhsin, "Sinergi antara Khat Imla' dan Bi'ah Lughawiyah dalam Meningkatkan Maharah Kitabah dan Istima' pada Pembelajaran Bahasa Arab” Volume 02, nomor 01 (Juli 2013).

13 Rina Dian Rahmawati and Amrini Shofiyani, "Strategi Pembelajaran Menulis Bahasa Arab Untuk Mahasiswa Program Studi Bahasa Inggris," Jurnal Education and Development 8, no. 3 (2020): 298.

14 Rathomi, "Maharah Kitabah Dalam Pembelajaran Bahasa Arab."

15 Dian Rahmawati and Shofiyani, "Strategi Pembelajaran Menulis Bahasa Arab Untuk Mahasiswa Program Studi Bahasa Inggris."
} 
dan media lainnya), terkecuali jikalau terdapat siswa yag tidak bisa melakukan melalui daring barulah dipersilahkan untuk langsung datang ke sekolah, karena ada beberapa guru yang juga tetap masuk setiap harinya secara bergantian untuk piket selama pandemi ini.

Adapun tahapan di setiap pelaksanaan pembelajaran Imla' pada murid kelas III ialah sebagai berikut: pertama, Sebelum mengadakan pertemuan dengan para murid, setidaknya sudah saling konfirmasi antara guru dengan murid terkait kapan waktunya ingin dimulai, pembelajaran dilaksanakan melalui apa, dan konfirmasi terkait hal yang lainnya.

Kedua, Via Whatsapp: diawali salam, doa, kemudian guru mengirimkan materi yang akan dibahas (bisa berupa video yang sudah direkam sekaligus penjelasan materinya dengan sejelas mungkin) ke grup, contoh: pembahasan tentang kosakata dari materi الأمر اض (seputar kejelasan cara baca, arti dan ekspresi) dan menulis huruf صetika diawal, ditengah dan diakhir atau dalam sebuah kata ataupun kalimat), lalu guru menjelaskan atau memberikan perintah sejelas mungkin terkait apa yang dikirimnya itu (bisa berupa pesan teks ataupun voice note), sehingga para murid paham apa yang diminta oleh guru. 10 hingga 15 menit setelah materi dibagikan, guru dan siswa bisa berdiskusi atau bertanya tentang materi yang sudah dijelaskan sebelumnya, hingga pada akhirnya masuk pada sesi latihan.

\section{Gambar 1. Aktivitas pembelajaran via Whats App}

Assalamuaikum wr wb Mas \& Mbak kelas 3 semuanya (C)

Bagaimana kabarnya semuanya? semoga kita sehat selalu di manapun kita berada ya $\mathbb{d}$

Saya M. Afief Akbari (bisa dipanggil mas Afif) dari kampus UIN Malang mohon izin sekaligus minta sedikit waktu untuk bisa belajar bahasa Arab bareng dengan kalian ya (0)

Mas \& mbak semuanya, nanti mas akan ngirim video tentang materi yang akan dibahas (seperti video penjelasan yang biasa dikirim oleh Pak Aslam) . lalu mas \& mbak semua mendengarkan penjelasan dari video tersebut, kemudian 10 atau 15 menit setelah itu mas \& mbak menjawab sedikit latihan dari apa yang telah kita pelajari terkait materi tersebut ya.

nanti jam 7 saya kirim video pembahasannya geh, kita belajar via grup whatsapp ini saja terimakasih sebelumnya (ㄷ) 1. 
TSAQOFIYA: Jurnal Pendidikan Bahasa dan Sastra, 3 (2), 2021

Gambar 2. Aktivitas pembelajaran via Whats App

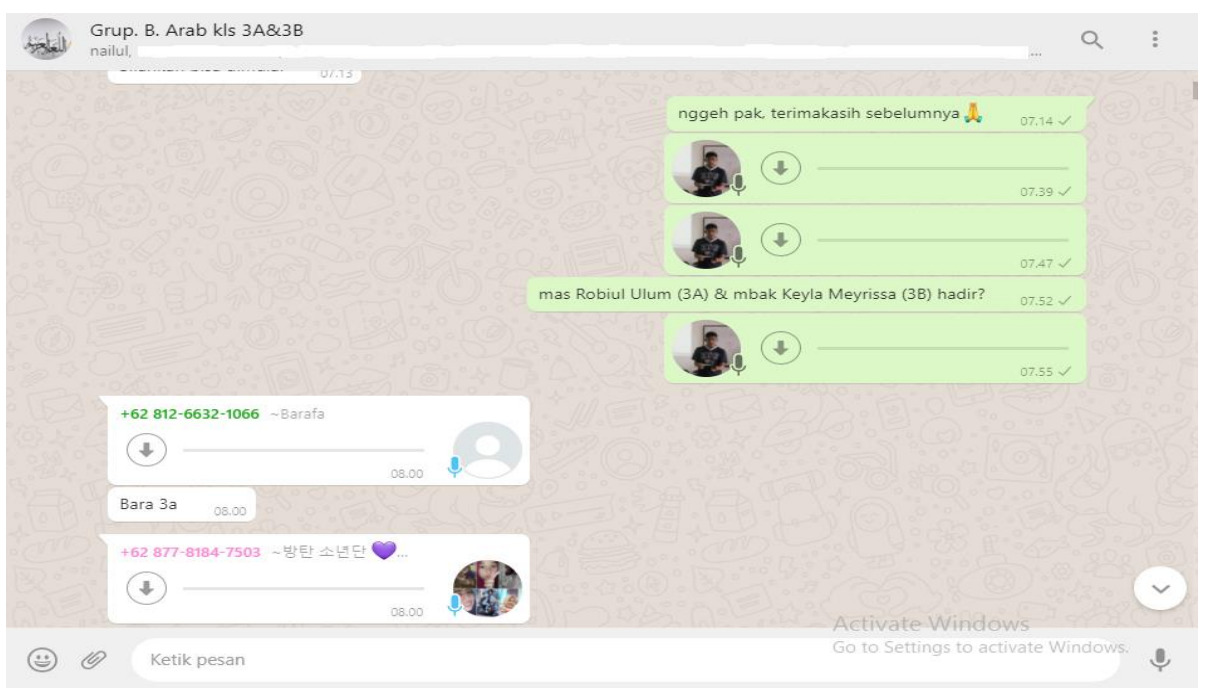

Gambar 3. Aktivitas pembelajaran via Whats App

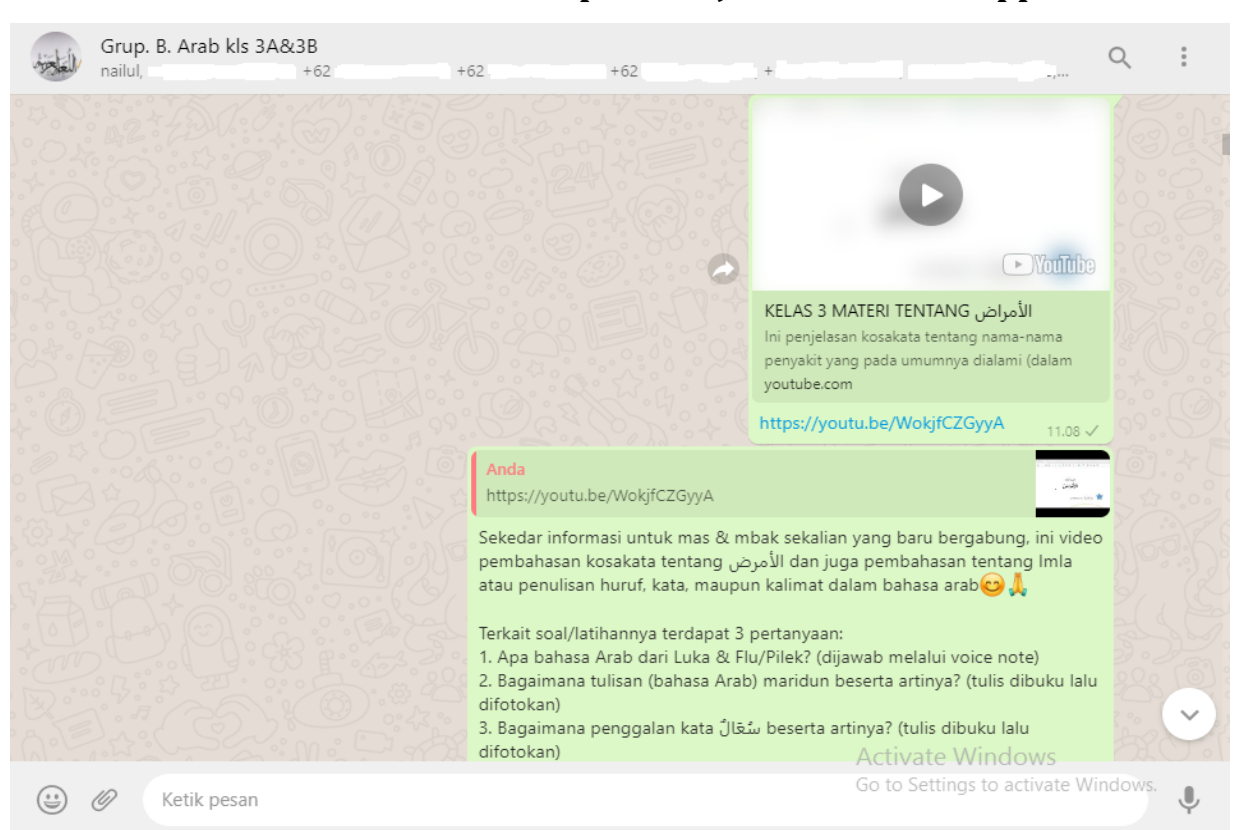

Ketiga, Via Zoom Meeting: guru dan murid melakukan pembelajaran pada jam 07.15, diawali dengan salam, lalu doa bersama sebelum mulai belajar yang dipimpin oleh ketua kelas, kemudian guru menanyakan sekilas kepada para murid terkait materi yang dibahas pada hari sebelumnya (baik secara pelafalan ataupun tulisan). Masuk pada pembahasan materi baru (percakapan yang dibungkus menjadi sebuah cerita) guru dalam pembahasannya menyampaikan seputar kejelasan cara baca, arti maupun maksud dan pengekspresian. Lalu guru dan murid melakukan diskusi ataupun tanya jawab terkait materi yang telah disampaikan sebelumnya (arti perkosakata ataupun maksud dari kalimat yang ada di pembahasan), kemudian dilanjutkan ke sesi latihan. 
Gambar 4. Aktivitas pembelajaran via Whats App

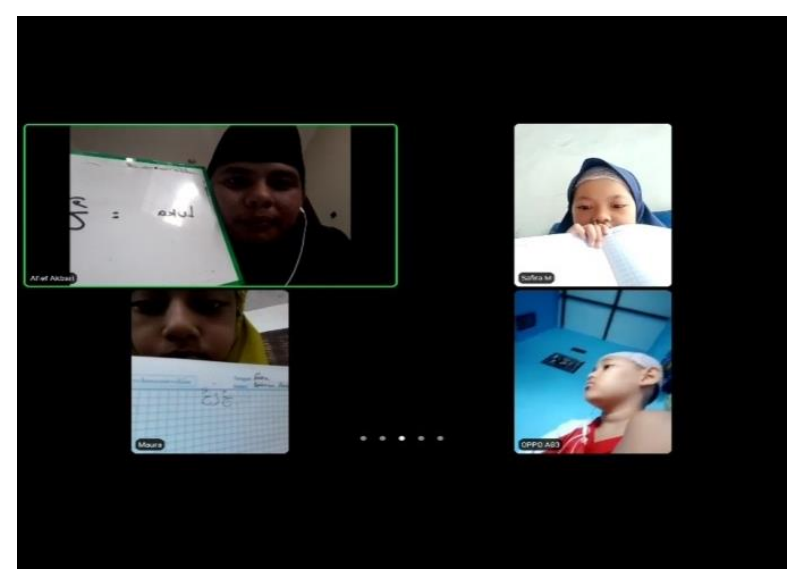

Keempat, Tahapan selanjutnya terkait latihan materi; seletah materi disampaikan dan juga sudah tahap diskusi ataupun tanya jawab, guru mengirimkan pesan teks ataupun voice note ke grup yang berisi meminta para murid untuk mengerjakan latihan yang diberikan, adapun soal-soal untuk latihannya sebagai berikut: 1. Apa bahasa Arab dari Luka \& Flu/Pilek? (dijawab melalui voice note), 2. Bagaimana tulisan (bahasa Arab) maridun beserta artinya? (tulis dibuku lalu difotokan), 3. Bagaimana penggalan kata سُعَالٌ beserta artinya? (tulis dibuku lalu difotokan), 4. Tuliskan kalimat "ashoobanii mabthun, asy'uru bi maghshin syadiidin" dalam bahasa Arab!. Terkait latihan atau penugasan ini, guru bisa meminta kepada muridnya untuk menjawab melalui pesan teks, voice note ataupun ditulis di buku kemudian difotokan.

Gambar 5. Hasil belajar menulis siswa

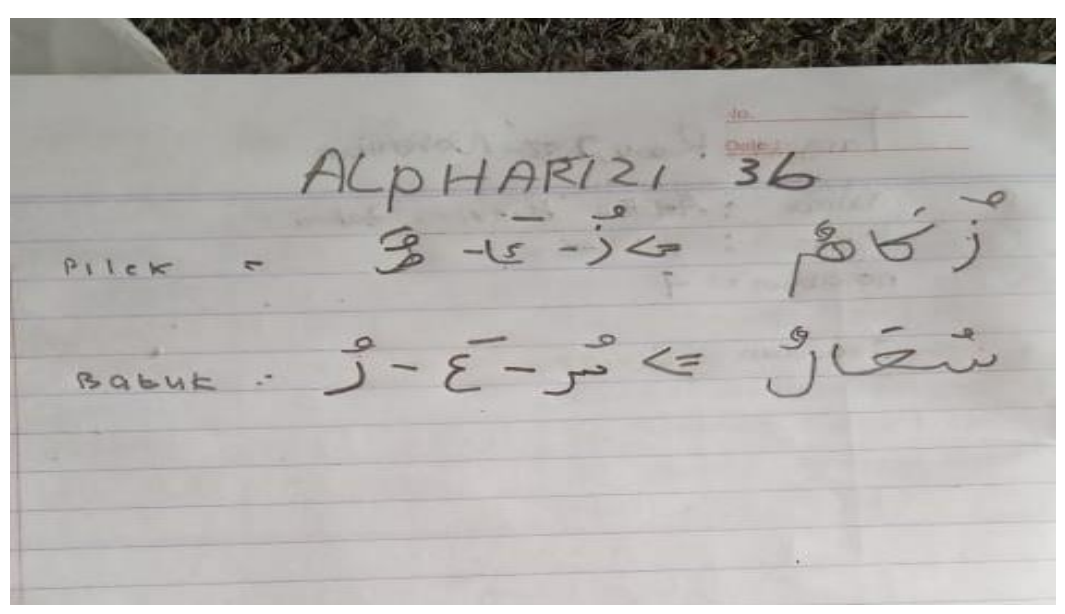


Gambar 6. Hasil belajar menulis siswa

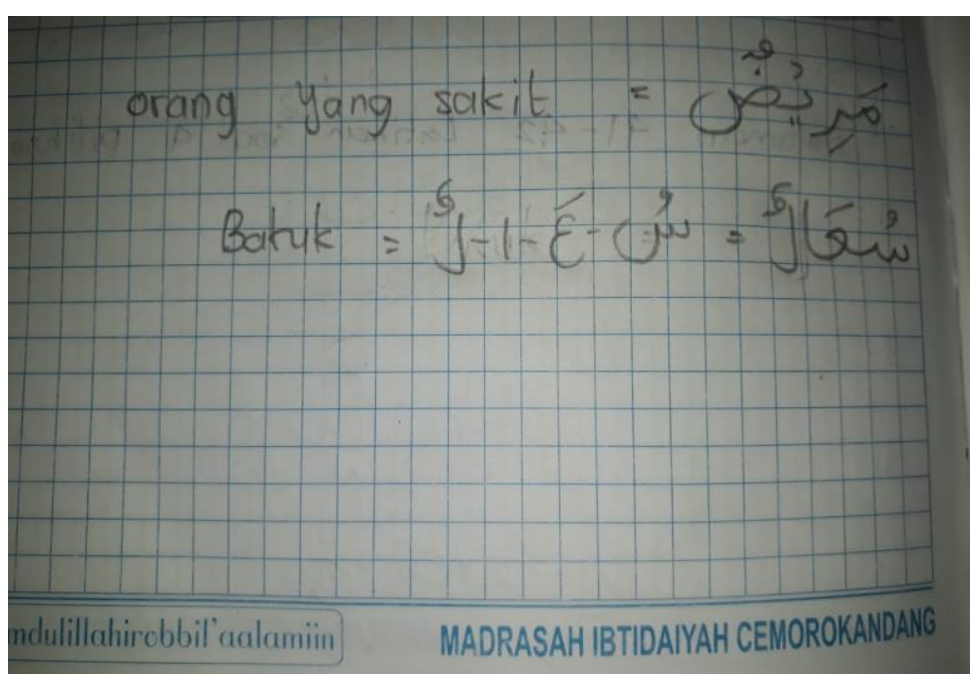

Gambar 7. Hasil belajar menulis siswa

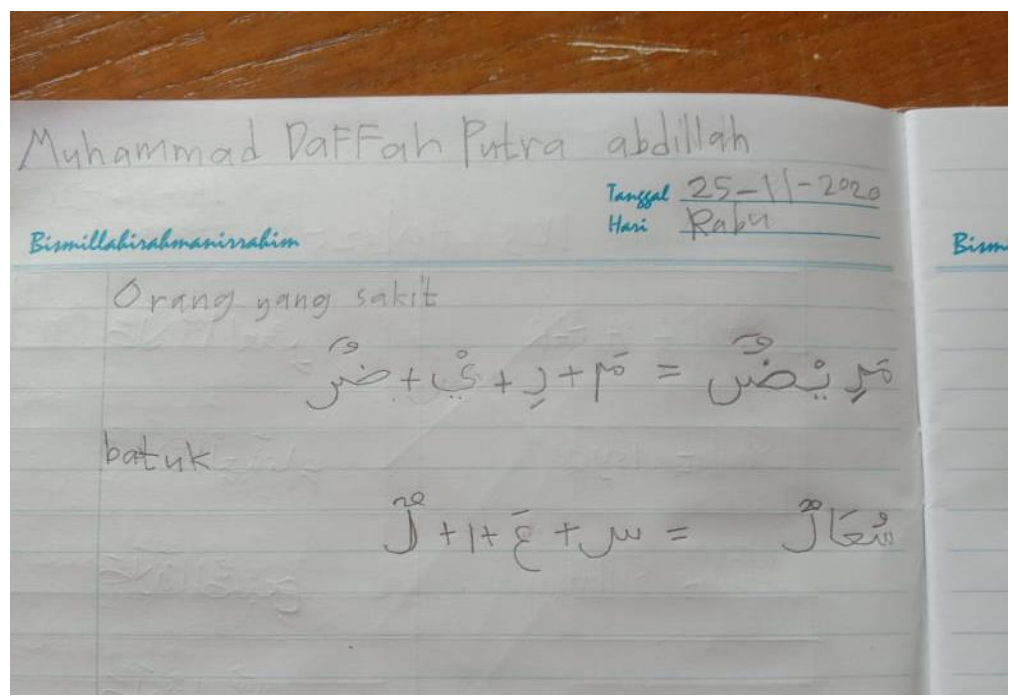

Kelima, Tahapan terakhir yakni penutup, ketika mengakhiri suatu pertemuan di dalam kegiatan belajar mengajar, guru bisa menyampaikan ulang materi yang sudah dibahas secara sekilas, yang itu bertujuan untuk sebagai penguat pemahaman dari maeri yang sudah dipelajari.

Kegiatan belajar mengajar yang dilaksanakan di kelas III MI Cemorokandang untuk materi Imla' telah dijalankan berdasarkan teori pembelajaran Imla' yang ada. Melihat dari tahapan pembelajaran yang sudah disampaikan sebelumnya bahwa guru telah memberikan instruksi pada siswa untuk membaca materi yang telah disampaikan (teks berbahasa Arab) kemudian mereka menuliskan teks tersebut. Pada proses menulis itu para murid diperbolehkan untuk melihat tulisan yang sedang mereka pindahkan ke buku tulis, gambaran ini merupakan hal yang sama yang itu juga disampaikan oleh Imla' Manqul. 
Selanjutnya juga sama dengan apa yang disampaikan oleh Imla Mandhur, pada tahapan pembelajaran Imla' yang dilaksanakan di kelas III MI Cemorokandang, guru meminta para murid untuk melihat ataupun membaca dengan cermat \& teliti terkait materi yang telah diajarkan, setelah itu para murid diminta untuk menuliskan teks yang sudah diteliti itu untuk menuliskan lagi ke buku mereka dengan tidak melihat lagi tulisan tersebut. Hal ini pula menandakan bahwa pembelajaran Imla' yang terlaksana sudah sesuai dengan teori pembelajaran Imla' yang ada.

\section{Dampak dari pembelajaran Imla' yang dilaksanakan}

Pembelajaran Imla' yang telah dilaksanakan di kelas III MI Cemorokandang diharapkan ataupun setidaknya memberikan dampak yang positif kepada para murid yang itu berkaitan dengan tujuan dari pembelajaran Imla' itu sendiri. Dampak ataupun hasil dari proses pembelajaran Imla yang sudah dilaksanakan, dengan memberikan beberapa pertanyaan kepada para murid dan juga guru mapel bahasa Arab kelas III MI Cemorokandang, adapun pertanyaan-pertanyaannya sebagai berikut: 1. apakah mas Afief ketika praktik mengajar kemarin benar-benar mempraktekkan cara mengucapkan atau cara penulisan bahasa arab dengan benar? (contoh pengucapan kosakata سعال), 2. apakah mas Afief mempraktikkan berbagai macam penulisan huruf, kata ataupun kalimat ketika mengajar kemarin? (contoh penulisan huruf $\tau$ ketika diawal, ditengah ataupun diakhir kata), 3. bagaimana menurut anak-anak tentang cara mengajar mas Afief? apakah menarik, mudah dipahami, interaktif dll?, sedangkan pertanyaan yang ditujukan untuk guru mapel bahasa Arabnya ialah: bagaimana praktik pembelajaran yang saya laksanakan kemarin? apakah setting pembelajaran yang saya buat kemarin sudah sesuai dengan rutinitas kegiatan belajar mengajar di sekolah itu? apakah materi yang diajarkan sudah sesuai dengan tujuan yang ingin dicapai dll?

Terkait pertanyaan tentang keseriusan ataupun kesungguhan dalam mempraktekkan cara mengucapkan atau cara penulisan bahasa arab dengan benar, para murid ataupun walinya menyatakan bahwa pengajar telah mempraktekkan cara pengucapan \& cara penulisan bahasa arab dengan sungguh-sungguh ataupun serius, lalu dalam hal pemraktikkan berbagai macam penulisan huruf, kata ataupun kalimat selama mengajar, para murid dan wali murid mengatakan bahwa pengajar sudah mempraktikkan berbagai macam penulisan huruf, kata ataupun kalimat ketika 
mengajar, kemudian terkait cara mengajarnya secara keseluruhan, para murid maupun walinya menyampaikan bahwa mereka puas dengan cara mengajarnya walaupun hanya melalui daring, karena menarik, mudah dipahami, interaktif dan lainnya, hanya saja masukkannya tentang kurang jelasnya terkait penugasan, sehingga mereka perlu untuk berkonsultasi secara pribadi supaya tugas itu lebih jelas.

Sedangkan pertanyaan terkait praktik pembelajaran yang dilaksanakan, kesesuaian setting pembelajaran yang dibuat dengan rutinitas kegiatan belajar mengajar yang ada di MI Cemorokandang, serta kesesuaian materi yang diajarkan dengan tujuan yang ingin dicapai, menurut pandangan pak Aslam yang itu merupakan guru mapel ini mengatakan bahwa praktik pembelajaran yang dilaksanakan sudah bagus, dikatakan demikian karena walaupun pembelajaran dengan media Whatsapp tapi anak-anak sudah bisa merespon jawaban dengan baik ataupun dengan benar, kemudian terkait setting pembelajaran yang dibuat dengan rutinitas kegiatan belajar mengajar yang ada di MI Cemorokandang sudah sesuai seperti yang para guru biasa lakukan pada masa pandemi ini (mengirim tugas, memberikan materi berupa video, kemudian anak-anak mengerjakan), lalu terkait materi yang diajarkan dengan tujuan yang ingin dicapai beliau mengatakan telah sesuai, dalam arti disuruh menulis, belajar menulis, bagaimana menulis huruf $\tau$ ketika diawal, ditengah ataupun diakhir kata, sudah divisualisasikan sehingga anakanak bisa menirukan materi yang diajarkan, walaupun sedikit-banyak memang masih ada beberapa yang salah.

\section{SIMPULAN}

Pembelajaran Imla' yang diajarkan melalui media online yaitu Whatsapp di kelas III MI Cemorokandang telah mencerminkan keberhasilan dalam memahamkan murid, dengan bukti bahwa para murid dapat menuliskan huruf, kata ataupun kalimat dalam bahasa Arab dan juga mereka bisa membedakan terkait huruf, kata, ataupun kalimat berbahasa Arab yang diucapkan oleh guru, sehingga dapat menuliskannya dengan benar.

Penelitian ini memiliki kekurangan dalam hal praktik pembelajaran yang dilaksanakan, dalam proses kegiatan belajar mengajar yang sudah dilakukan (via Whatsapp ataupun Zoom Meeting) dirasa masih belum maksimal, karena terdapat 
beberapa faktor yang itu diluar dugaan akan menggangu kelancaraan pembelajaran ini, seperti koneksi yang terputus secara tiba-tiba, handphone sudah terlanjur dibawa kerja dan lain sebagainya. Penelitian ini menyarankan, ketika ingin melaksanakan kegiatan belajar mengajar di era pandemi seperti sekarang ini dan di tingkat MI/SD yang itu sekiranya membutuhkan bimbingan dari orang tuanya, perlu sekali untuk dipersiapkan sedetail, sesiap dan semaksimal mungkin, sehingga bisa meminimalisir hal-hal yang tidak diinginkan mengganggu.

\section{DAFTAR PUSTAKA}

Abdul Aziz S Syamsu Nahar, Mardianto. "Desain Pembelajaran Imla'dalam Meningkatkan Kemampuan Menulis Tulisan Arab Bagi Santri Di Pondok Pesantren Ar-Raudlatul Hasanah Medan." Edu-Riligia: Jurnal Ilmu Pendidikan Islam Dan Keagamaan 1, no. 4 (2017).

Dian Rahmawati, Rina, and Amrini Shofiyani. "Strategi Pembelajaran Menulis Bahasa Arab Untuk Mahasiswa Program Studi Bahasa Inggris." Jurnal Education and Development 8, no. 3 (2020): 298.

Hijrat, Lalu Akmal. “Pembelajaran Khat Wa Qowa'idul Imla' Mahasiswa UIN Mataram Dan Problematikanya." Al-Islamiyah, Jurnal Pendidikan Dan Wawasan Studi Islam 2, no. 1 (2020): 1-8.

Moleong, Lexy J. Metodologi Penelitian Kualitatif. PT Remaja Rosdakarya. Bandung: PT Remaja Rosdakarya, 2009.

Rathomi, Ahmad. "Maharah Kitabah Dalam Pembelajaran Bahasa Arab." Tarbiya Islamica 1, no. 1 (2020): 1-8.

Rini, Rini. "Pembelajaran Kemahiran Menulis Bahasa Arab Aplikatif." Al-Muktamar AsSanawi Li Al-Lughah Al-'Arabiyyah (MUSLA) 1, no. 1 (2020): 18-42.

Siyoto, Sandu, and Muhammad Ali Sodik. Dasar Metodologi Penelitian. Literasi Media Publishing, 2015. 